\title{
MIGRATORY ABILITY OF ORCONECTES LIMOSUS THROUGH A FISHPASS AND NOTES ON ITS OCCURRENCE IN THE CZECH REPUBLIC
}

\author{
P. KOZÁK (1), T. POLICAR (1), Z. ĎURIŠ (2)
}
(1) University of South Bohemia in České Budějovice, Research Institute of Fish Culture and Hydrobiology at Vodňany, Czech Republic.
E-Mail: kozak@vurh.jcu.cz

(2) Department of Biology, University of Ostrava, Ostrava, Czech Republic

Reçu le 6 janvier 2004

Received January 6, 2004

Accepté le 7 juin 2004

Accepted June 7, 2004

\begin{abstract}
The occurrence of the spiny-cheek crayfish in the Czech Republic was first reported in the 1980's in the Elbe River and is a result of its upstream migration from Germany. This study confirms that this species occurs in many other localities across the Czech Republic. Its migration ability was experimentally studied at a thirty-chambers fishpass located at a hydroelectric power station in the Elbe River. Group-marked crayfish were placed into 3 selected chambers. Their up- and downstream movement was then registered for $30 \mathrm{~min}$ after crayfish stocking. We found that a large portion of the experimental crayfish was passively carried along the stream and was caught in the lowest chamber. The movement of crayfish against the water current towards the higher-positioned chambers was not recorded. However, crayfish showed to have a high ability to hold their position in a strong water flow. Overall, $56.7 \pm 9.43 \%, 6.7 \pm 9.43 \%$ and $3.3 \pm 4.71 \%$ of crayfish remained in the chamber of insertion and $23.3 \pm 4.71 \%, 30.0 \pm 14.14 \%$ and $26.7 \pm 17.00 \%$ of crayfish migrated to the lower-positioned chambers.
\end{abstract}

Key-words: Crayfish, Orconectes limosus, distribution, Czech Republic, activity, migration, fishpass.

\section{CAPACITÉ MIGRATOIRE D'ORCONECTES LIMOSUS À TRAVERS UNE PASSE À POISSONS ET NOTES SUR SA PRÉSENCE EN RÉPUBLIQUE TCHÈQUE}

\section{RÉSUMÉ}

La présence de l'écrevisse américaine Orconectes limosus en République Tchèque a été établie pour la première fois dans les années 1980 dans l'Elbe comme le résultat d'une migration vers l'amont du fleuve à partir de l'Allemagne. Nous confirmons que l'espèce est également présente dans d'autres localités en République Tchèque. Sa capacité de migration a été étudiée expérimentalement sur une passe à poissons d'une station hydroélectrique de l'Elbe composée de 30 réservoirs. Des écrevisses marquées par groupe ont été placées dans 3 réservoirs. Leurs déplacements vers l'amont et vers l'aval ont été mesurés 30 minutes après que les écrevisses ont été placées dans les réservoirs. II apparaît qu'une partie de ces écrevisses ont dérivé passivement avec le courant car elles ont été retrouvées dans le réservoir le plus bas. Cependant, d'autres écrevisses ont 
été capables de maintenir leur position dans un courant puissant. Aucun mouvement des écrevisses opposé au courant, c'est à dire vers les réservoirs supérieurs n'a été observé. En tout, $56,7 \pm 9,43 \%, 6,7 \pm 9,43 \%$ et $3,3 \pm 4,71 \%$ des écrevisses sont restées dans le réservoir où on les a mises. En plus, $23,3 \pm 4,71 \%, 30,0 \pm 14,14 \%$ et $26,7 \pm 17,00 \%$ des écrevisses ont migré vers les réservoirs plus bas.

Mots-clés: Écrevisse, Orconectes limosus, distribution, République Tchèque, activité, migration, passe à poisson.

\section{INTRODUCTION}

The spiny-cheek crayfish (Orconectes limosus) is originally native to the east coast of the USA and Canada (HOBBS, 1974; HAMR, 2002). This species was imported to Western Europe (Germany) in 1890. Nowadays, it is widely distributed throughout most Western- and Central European countries (HOLDICH et al., 1999). Apart from Europe, its occurrence has also been observed in Morocco, where the species successfully acclimated (MOUSLIH, 1987). Since 1988, the spiny-cheek crayfish was known to occur in waters of the today Czech Republic and in particular in the Elbe (Labe) River by Ústí nad Labem city (HAJER, 1989). Since that time, it has spread widely, due to its natural dispersive potential or as a result of anthropogenic translocations. This species is a vector of the crayfish plague, lethally affecting populations of the noble crayfish, Astacus astacus. For this reason, its migration has been carefully monitored.

Several authors proved the migratory ability of the spiny-cheek crayfish (LEŃKOWA, 1962; LAURENT, 1997; LINDQVIST and HUNER, 1999). We studied the movement through a hydroelectric power plant fishpass in the Elbe River in an in situ experiment to verify the migration potential of spiny-cheek crayfish. The aim of this study was twofold. First, we described the present distribution of O. limosus in the Czech Republic and, second, we aimed providing a contribution to the knowledge of its migration potential. The question we addressed was to find out wether crayfish are able to maintain their position or to migrate upstream even when subjected to fast water current.

\section{MATERIAL AND METHODS}

\section{Distribution}

The distribution of the species was studied along the Elbe River, the Vltava River (including dam reservoirs) and other selected waterbodies in the period from 1998-2003. The occurrence of this crayfish was monitored in every location by direct observations from the banks during diurnal and nocturnal hours. Individuals were caught by hand or using baited traps.

\section{Migratory ability}

The experiment was conducted in a thirty-chambered fishpass of a hydroelectric power station in the Elbe River in Obrríství. Construction of weir, with hydroelectric power plant, fishpass, and, shipping channel (85 m length), which enable naval shipping, was finished in 1976. The fall of the water level is $4 \mathrm{~m}$. The fishpass is not located in the littoral zone of the river, but between turbine and weir (about $20 \mathrm{~m}$ from a river bank). The chambers of fishpass, except the top one, measured $1.2 \times 1 \times 0.5 \mathrm{~m}$. Each chamber had on the up and down wall 2 squared holes of $0.20 \times 0.15 \mathrm{~m}$ in its lower and in the upper part that enable the passage of fish either on the bottom or over arm (Figure 1). Velocity of the water current through the fishpass was about $0.2 \mathrm{~m}^{-1} \mathrm{~s}^{-1}$ with very fast turbulences (2 $\left.\mathrm{m} . \mathrm{s}^{-1}\right)$. The top chamber was $10 \mathrm{~m}$ longer and was characterised by slower water currents and by sections without current or with counterblows. 


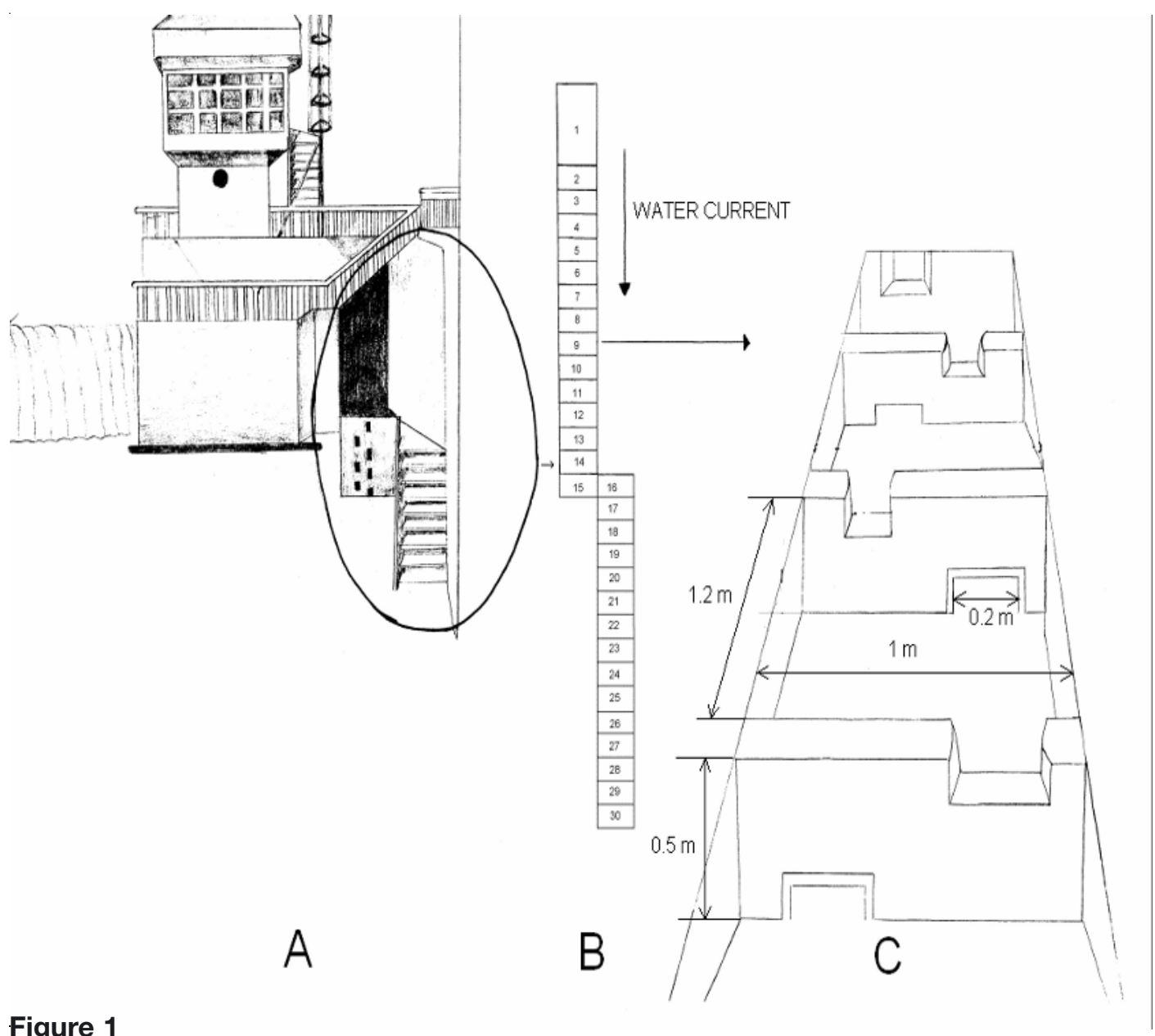

Figure 1

Scheme of a thirty-chambered fishpass of a hydro-electric power station in the Elbe River in Obříství (A - general view, B - scheme of the fishpass, C - details of the chambers).

Figure 1

Schéma d'une passe à poissons composée de 30 réservoirs dans une station hydroélectrique de la rivière Elbe à Obříství ( $A$ - vue générale, $B$ - schéma d'une passe à poissons, $\mathrm{C}$ - détail du réservoir).

Crayfish used for the experiments were caught in the river $24 \mathrm{hrs}$ prior to the experiment from sections that were up - or downstream - the fishpass. All the captured crayfish were measured and those selected for the experiment were marked by hot branding with gas solder, a different mark for a different group. Groups of crayfish were composed of specimens of approximately the same size. Experimental crayfish had a mean total length of $67.2 \pm 11.29 \mathrm{~mm}$ and a mean cephalothorax length of $31.9 \pm 5.92 \mathrm{~mm}$. The fish-pass was drained off prior to the experiment to exclude any crayfish that may have been present prior to the experiment. After having refilled the fishpass with water, three chambers were selected for the experiment and each was stocked with a group of 10 crayfish. Experimental chambers included the top chamber (No. 1) and 2 other chambers (No. 15 and 19), randomly chosen among the 30 chambers of the fishpass of the standard size. Crayfish were maintained in the fishpass for $30 \mathrm{~min}$. Experiment was repeated three times (July 11, 2001, July 11, 2001 after 1 hr break, August 29, 2001). After 30 minutes, the fishpass was drained off again and the position of every crayfish was 
recorded. To prevent crayfish from being flushed away during the process of draining off, all chambers were closed off with nets immediately before the draining off process. To prevent downstream flushing of crayfish from the fishpass, both the upper and lower holes of the last chamber above the water level were closed with a net for the whole time of the experiment. After the draining off process, the crayfish flushed to this net were considered as crayfish caught in the lowest chamber. Impact of chamber on crayfish migration was analysed by one-way ANOVA ( $\alpha<0.01$, Microsoft Excel XP).

\section{RESULTS}

\section{Distribution}

The spiny-cheek crayfish was present in all of the surveyed portions of the Elbe River from the German border upstream to Pardubice, and in the Vltava River from its confluence with the Elbe River upstream to České Budějovice, and also in the cascade of dam reservoirs on the Vltava River. In those sections where crayfish were not found, either their occurrence could not be excluded or habitat conditions were unfavourable for crayfish (lack of shelters - Slapy, Orlík by Podholušice, or low water temperature - Kamýk nad Vltavou). Furthermore, the spiny-cheek crayfish was recorded in Ohře, Otava and Lužnice rivers, as well as in the Golden Channel and in Pšovka, Hrejkovický and Nový brooks, and in a flooded quarry Na skále by Starý Klíčov village (Domažlice district) and in other waterbodies (Figure 2).

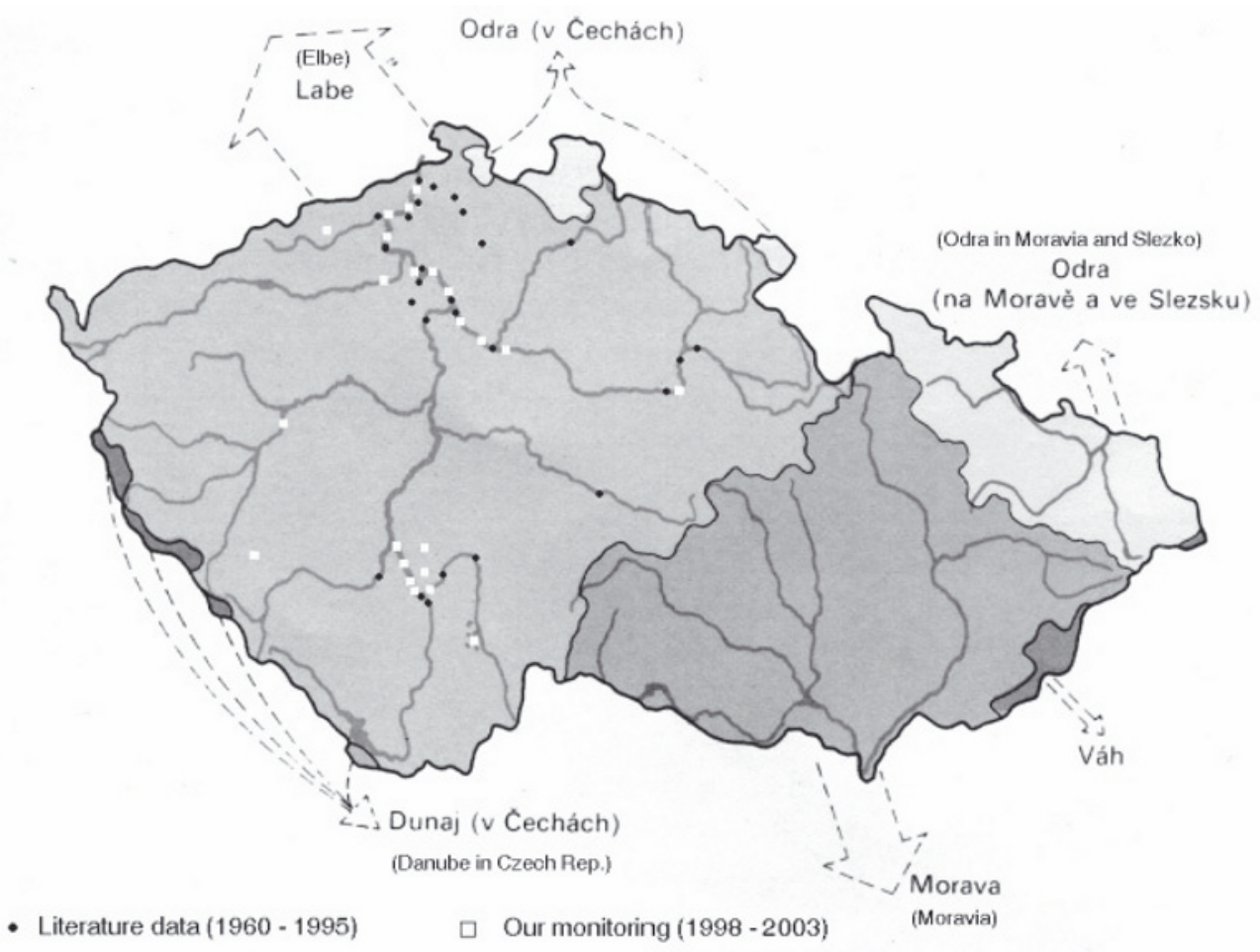

Figure 2

The occurrence of spiny-cheek crayfish according to data from the literature and from a monitoring campaign conducted from 1998 to 2003.

\section{Figure 2}

Présence de l'écrevisse américaine Orconectes limosus, selon les données de la littérature, et d'après les informations obtenues pendant la campagne de suivi de 1998 à 2003. 


\section{Migratory ability}

Crayfish did not show any upstream movement from lower and higher chambers. Crayfish either remained in the same chamber to which they had been introduced, or they moved actively or passively to the chambers positioned downstream. The majority of crayfish $(20.0 \pm 14.14 \%, 53.3 \pm 20.55 \%$ and $70.0 \pm 16.33 \%$ for chambers No. 1,15 and 19 , respectively) were found in the lowest chamber of the fishpass. After $30 \mathrm{~min}$, $56.7 \pm 9.43 \%$ of crayfish remained in the chamber No. 1 . The ability to keep that position is statistically higher than in the other two lower-positioned chambers (No. 15 and 19), where only $6.7 \pm 9.43 \%$ and $3.3 \pm 4.71 \%$ of crayfish maintained their position (Table 1). Some crayfish migrated to lower-positioned chambers. Altogether, $23.3 \pm 4.71 \%, 30.0 \pm 14.14 \%$ and $26.7 \pm 17.00 \%$ of crayfish migrated to the lower-positioned chambers from chambers No. 1,15 and 19, respectively. On the $29^{\text {th }}$ of August 2001 (before stocking of experimental crayfish), one unmarked crayfish was found in chamber No. 28 which remained filled with water after the draining off process. This was not an experimental crayfish, but it probably entered the fishpass from the outside.

\section{Table I}

Frequency (in \%) of spiny-cheek crayfish after $\mathbf{3 0}$ min from their insertion into fishpass chambers. Groups in columns with the same alphabetic superscript do not differ significantly at $\mathrm{P}<0.01$.

\section{Tableau I}

Quantité d'écrevisses américaines (en \%), observées $30 \mathrm{mn}$ après leur introduction dans les réservoirs individuels de la passe à poisson. Les groupes en colonnes avec la même lettre en exposant ne diffèrent pas significativement à $P<0,01$.

\begin{tabular}{lccc}
\hline \multirow{2}{*}{ Crayfish found } & $\mathbf{1}$ & $\mathbf{3}$ & $\mathbf{1 9}$ \\
\cline { 2 - 4 } & $56.7 \pm 9.43^{\mathrm{b}}$ & $6.7 \pm 9.43^{\mathrm{a}}$ & $3.3 \pm 4.71^{\mathrm{a}}$ \\
\hline $\begin{array}{l}\text { In the chamber of } \\
\text { insertion }\end{array}$ & $23.3 \pm 4.71^{\mathrm{a}}$ & $30.0 \pm 14.14^{\mathrm{a}}$ & $26.7 \pm 17.00^{\mathrm{a}}$ \\
\hline In a lower chamber & $20.0 \pm 14.14^{\mathrm{a}}$ & $53.3 \pm 20.55^{\mathrm{ab}}$ & $70.0 \pm 16.33^{\mathrm{b}}$ \\
\hline In the lowest chamber & &
\end{tabular}

\section{DISCUSSION AND CONCLUSION}

The spiny-cheek crayfish occupies the main portions of the largest Czech rivers, i.e. Elbe and VItava, and it has also spread to some of their tributaries. When the waterbodies of the present day Czech Republic are considered, it was recorded for the first time by HAJER (1989) in the Elbe River by Ústí nad Labem in 1988. At the beginning of the 1990's, it was found in the Elbe River from Děčín upstream to Hradec Králové, also in the Vltava River upstream to České Budějovice, in the Berounka River by Plzeň (Pilsen) and in their tributaries (HAJER, 1994). According to the available data it appears that the spiny-cheek crayfish spread into the Czech Republic via the Elbe River even before 1960 (HAJER, 1995) and since that time it has been spreading further into Bohemia. Orconectes limosus has still not been observed in Moravia, but it is possible that it will spread there from Bohemia through the Sázava River. Another potential way of spreading could be the Odra River (HAJER, 1994), and the hydrological system of the upper Vistula River basin in Poland 
where the spiny cheek crayfish is already dominant (KRZYŹANEK and KASZA, 1998; DURIŠ, 1999), with the native species (A. astacus, A. leptodactylus) close to extinction (MASTYŃSKI and ANDRZEJEWSKI, 2000). The presence of $O$. limosus in isolated aquatic bodies (localities surveyed mostly by scuba diving and fishing) gives evidence that human translocation has played a role in the spreading of this crayfish species.

European studies on $O$. limosus have mostly focused on the distribution and the spreading of this species. LAURENT (1997) claims that it migrates into and colonizes new localities more easily because of its early sexual maturation, high fertility, resistance to crayfish plague, and aggressiveness. Its diffusion is not natural, but requires the help of man (LAURENT, 1997). There are data illustrating its ability to occupy new areas such as the Biale Lake in Poland, close to the border with Ukraine and Belarus, which was one of the very few remained localities occupied by the narrow clawed crayfish. STRUŽYŃSKI and NIEMIEC (2000) captured the first specimen of spiny-cheek crayfish (an adult female) in the lake in 1997, and despite their intensive research, they did not find any other specimens. Two juveniles were captured in 1998, and six juveniles and one adult female in 1999. Two brief night surveys of the same lake in the autumn 2001 revealed the presence of 20 specimens. The authors explained the presence of the spiny-cheek crayfish in that region as the effect of fishermen who used crayfish abdomens as bait for eel fishing, as well as of the natural diffusion of the crayfish from other localities.

During our fishpass migration experiment, we have not recorded a single case of crayfish movement upstream, from downstream-positioned chambers. Some crayfish in our study were capable to maintain their position in the fishpass chambers for a certain time, others were passively carried by the strong water flow and they were flushed out of the chamber in several minutes. When crayfish were stocked to the first chamber (No. 1) without strong turbulences, then majority of the crayfish maintained their position in this chamber or in any lower positioned chambers. When crayfish were stocked to chambers with strong turbulence, they were probably flushed down to the lower chamber and only some of them were able to keep their position in any of the chambers of the fishpass. The maintenance of their position in the fishpass for a relatively long time under certain condition is a proof of their ability to resist strong water flow (up to $2 \mathrm{~m} . \mathrm{s}^{-1}$ ). On the other hand, crayfish can use the fishpass for migrating only occasionally, because it is not located in the littoral zone of the river, which is mostly used by crayfish. Additionally, the entrance and exit holes in the fishpass were placed very high above the riverbed, where crayfish mostly occur. The more likely route for crayfish migration is the shipping channel ( $85 \mathrm{~m}$ of length and $12 \mathrm{~m}$ of width) connecting the upstream and downstream portions of the river.

\section{ACKNOWLEDGEMENTS}

This investigation was financially supported by GACR projects No. 206/03/0532 No. 206/03/D064 and MSM project J06/98:126100003.

\section{REFERENCES}

ĎURIŠ Z., 1999. On the distribution of the introduced crayfish Orconectes limosus in Poland. Freshwater Crayfish, 12, 830-834.

HAJER J., 1989. Americký druh raka v Labi. /American crayfish in the Elbe river. Živa, 37(3), 125.

HAJER J., 1994. Expanze raků druhu Cambarus affinis Say ve vodách České republiky. Expanses of Cambarus affinis Say in The Czech Republic. Fauna Bohemiae septentrionalis, 19, 123-128. 
HAJER J., 1995. Stanovisko k článku pana Huberta Matouše. A point of view to article of Mr. Hubert Matouš. Rybářství, 9, 269.

HAMR P., 2002. Orconectes. In. Holdich DM (ed.) Biology of freshwater crayfish. Blackwell Science: Oxford, 585-609.

HAMRIN S.F., 1987. Seasonal crayfish activity as influenced by fluctuating water levels and presence of a fish predator. Holarctic Ecology, 10, 45-51.

HOBBS H.H., 1974. Synopsis of the Families and Genera of Crayfishes (Crustacea: Decapoda). Smithsonian Contributions to Zoology, 164, 33 pp.

HOLDICH D.M., ACKEFORS H., GHERARDI F., 1999. Native and alien crayfish in Europe: Some conclusions. In: F. GHERARDI, D.M. HOLDICH (eds), Crayfish in Europe as alien species. How to make the best from a bad situation? A.A. Balkema, Rotterdam, Brookfied, 281-292.

KRZYŹANEK E., KASZA H., 1998. Raki zbiornika Goczalkowickiego. Przyroda Górnego Śląska, (13), 13.

LAURENT P.J., 1997. Crayfish introduction into France and in the world, history and consequences. In: F. BERGOT et E. VIGNEUX (Eds.): Species introduction in the freshwater aquatic environment. Bull. Fr. Pêche Piscic., 344-345, 345-356.

LEŃKOWA A., 1962. Badania nad przyczynami zaniku, sposobami ochrony i restytucją raka szlachetnego Astacus astacus (L.) w związku z rozprzestrzenianiem się raka amerykańskiego Cambarus affinis Say. Ochrona Przyrody, 28, 1-38.

LINDQVIST O.V., HUNER J.V., 1999. Life history characteristics of crayfish: What makes some of them good colonizers? In: F. GHERARDI, D.M. HOLDICH (eds), Crayfish in Europe as alien species. How to make the best of a bad situation? A.A.Balkema: Rotterdam, Brookfield, 23-30.

MASTYŃSKI J., ANDRZEJEWSKI W., 2000. Stan populacji raków w wodach Polski Zachodniej ze szczególnym uwzglednieniem raka szlachetnego (Astacus astacus L.). In: J. MASTYŃSKI, W. ANDRZEJEWSKI (red.), Aktualny stan raków w Polsce. I.Sympozjum astakologów, Poznań, 06.10.2000, 29-30 (abstr.).

MOUSLIH, M., 1987: Fish and crayfish introductions in Morocco. Rev. Hydrobiol. Trop., $20,1,65-72$.

STRUŹYŃSKI W., NIEMIEC T., 2000. Wspólbytowanie raka blotnego (Astacus leptodactylus, Esch.) i raka pregowatego (Orconectes limosus, Raf.) w jeziorze Bialym. Szacunek dla wody, 18. Zjazd hydrobiologów polskich w Bialymstoku. Polskie towarzystwo hydrobiologiczne, Zaklad biologii ogólnej am w Bialymstoku, 4.-8.IX.2000, 252253. 
